\title{
Justice-making institutions and the ancestral logic of conflict
}

\author{
Daniel Sznycer ${ }^{\mathrm{a}}$, Aaron Sell $^{\mathrm{b}, \mathrm{c}}$, \& Keelah E. G. Williams ${ }^{\mathrm{d}}$ \\ aOklahoma Center for Evolutionary Analysis, Department of Psychology, Oklahoma State \\ University, Stillwater, OK, USA \\ ${ }^{b}$ Department of Psychology, Heidelberg University, Tiffin, OH, USA \\ ${ }^{\mathrm{c}}$ Department of Criminology, Heidelberg University, Tiffin, OH, USA \\ ${ }^{\mathrm{d}}$ Department of Psychology, Hamilton College, Clinton, NY, USA
}

Corresponding Author: Daniel Sznycer

E-mail: daniel.sznycer@okstate.edu

\begin{abstract}
Justice-making institutions rest on a vast network of rules, people, and artifacts. The federal criminal code of the United States, for example, has hundreds of sections with provisions for robbery and burglary, counterfeit bonds, chemical weapons, riots, expenditures to influence voting, and many others. This complexity can be traced to a handful of small-n-person games played by our foraging ancestors in their stateless societies. The overarching theme is conflict. Justice is predicated on actual or possible conflicts of interest. Individual brains include an array of adaptations that were selected because they regulated conflict-relevant behavior in fitnesspromoting fashion: concepts (e.g., WRONGFUL ACT, UNJUST DISTRIBUTION), intuitions (e.g., a wrong deserves a punishment), and emotion systems (e.g., anger), among others. These ancient adaptations appear to form the core of justice-making institutions in modern societies - a core that is augmented by deliberation and writing systems. This theory of justice-making institutions can generate distinctive predictions. For example, the logic of justice-making institutions will echo the logic of their source adaptations, and thus will be apparent in laypeople's naturalistic interactions. Further, laypeople will be able to intuitively recreate basic features of justicemaking institutions near and far, past and present - because they have a common human nature with domestic and foreign lawmakers. Here, we review evidence relevant to $(i)$ the criminal justice system and (ii) state-enacted redistribution in light of this adaptationist theory. We conclude that adaptationism is a productive framework to elucidate human institutions.
\end{abstract}




\section{Introduction}

The human notion of justice is predicated on conflicts of interest between fellow group members - there is no injustice to redress when interests are aligned, or when interests are misaligned but some conflict is the less costly alternative to escalation. Justice-making institutions, therefore, might be contraptions to deal with the problem of human-human conflict: conflict resulting from the emission of externalities; conflict resulting from accidents; conflict resulting from fraud, exploitation, and murder; conflict over how bads, goods, duties, and privileges ought to be distributed; and so on.

Justice-making institutions are complex. Even in small-scale, technologically-sparse societies, there is a host of special procedures for dealing with wrongdoing. These include: gossip, punishment, reparations, norms with supernatural sanction, customary courts, and rituals of reconciliation (Boehm, 1994; Bohannan, 2018; Wiessner, 2020).

This complexity has ballooned up in industrial, large-scale societies. Young children may be forgiven for thinking that if you break the law you go to prison (Dunlea \& Heiphetz, 2020), oblivious of the procedural gulf between "break the law" and "go to prison" (Neumeyer, 1968). But an institution such as the criminal justice system of the United States rests upon a mammoth set of rules, people, and artifacts arrayed just so. The federal criminal code of the United States alone, for example, has hundreds of sections with provisions for robbery and burglary, chemical weapons, vehicles falsely labeled as carriers, riots, relanding of goods, repacking goods in warehouses, expenditures to influence voting, conspiracy to impede or injure officers, illegal interception of communications, loss of rights, transfer of offenders on probation, health care for prisoners, appeal, and many others (United States Code, Supplement 5, Title 18 - Crimes and Criminal Procedure, 2011).

Distributive institutions too are vast and complex. To give a sense of scale, the Internal Revenue Service - the tax collection agency of the United States - has 74,000 employees and an annual budget of $\$ 11 \mathrm{~B}$ as of 2019, and they administer a tax code that is 2,652 pages long (United States Code, Title 26, Internal Revenue Code, 2012, p. 26). The folk notion that the government takes from the rich and gives to the poor is accurate but incomplete. There is (e.g., in the U.S.) a vast number of complex transfer schemes by the government to individuals and organizations, many of which are progressive and many of which are regressive (Moon, 1984; Tullock, 1983).

Where does this institutional complexity come from?

\section{The small-scale psychology of justice-making institutions}

Justice-making institutions can be traced to psychological adaptations found in individual brains (Tooby \& Cosmides, 1992; Cosmides \& Tooby, 2006; Robinson et al., 2007; Boyer \& Petersen, 2012; Lieberman \& Patrick, 2018; Sznycer \& Patrick, 2020).

This adaptationist hypothesis does not deny cultural, group-level selection effects (Bowles et al., 2003; Richerson \& Henrich, 2009). Institutions that generate more group-level benefits likely become more frequent over time, through expansion, war, conquest, or through cultural appropriation by others (Henrich, 2020; Landes, 2015; Sowell, 2021) — see, for example, the introduction of the corporation in the Middle East (Kuran, 2005). Unlike cultural group selection accounts, however, we suggest that the psychologies that shape the core of justice-making and other institutions - their invariant principles and their open parameters - have been shaped by gene-level selection. 
How can we know? At least two things can be expected if a gene-selected psychology shapes justice-making institutions. First, these institutions will echo the circuit logic of their source adaptations. If the proper domain of the relevant adaptations is small-n-person interactions within groups (Curry et al., 2019; DeScioli \& Kurzban, 2013; Gray et al., 2012; Krasnow et al., 2016; Sznycer et al., 2017; Tooby \& Cosmides, 2010), then basic features of justice-making institutions will be apparent in the naturalistic interactions of dyads, triads, and so on, when the adaptations meet their inputs (e.g., in how Y reacts when X defrauds $\mathrm{Y}$; in how Z reacts when $\mathrm{X}$ assaults $\mathrm{Y}$ ) - even when the individuals involved are laypeople with no explicit knowledge about, e.g., the criminal justice system. And second, signatures of the relevant adaptations, because by hypothesis they are human-universals, will be observed in justicemaking institutions broadly, across cultures and throughout history.

Here, we review evidence relevant to two justice-making institutions, $(i)$ the criminal justice system and (ii) progressive, government-enacted redistribution, in light of the preceding argument.

\section{Criminal justice}

The origins of criminal laws have puzzled people for millennia. Criminal laws have been traced variously to God (Plaut \& Bamberger, 1981), to social norms that vary across cultures (Braman et al., 2010; Durkheim, 1984), to utilitarianism (Bentham, 1907) and rational choice (Posner, 2010), and to objective moral facts that await discovery by legal experts (Blackstone, 1765; Dworkin, 1986).

In contrast, an adaptationist perspective suggests that laws against wrongdoing result from intuitions generated by the standard-issue human brain. More specifically, laws against wrongdoing - criminal laws, but also laws that give rise to civil claims such as torts, breaches of contract, and violations of property law - are generated by justice intuitions stemming from a social-evaluative psychology - a psychology that evolved because it would have helped our hominin ancestors interact with fellow group members.

Sociality is likely to have been net-beneficial for hominins, for modern humans to be, as we are, a social species (Daly \& Wilson, 1983). The human cost of being social is not trivial, however. Humans create externalities that adversely impact others. Also, humans benefit at the expense of others. Humans defraud, rob, rape, and exploit the capacities, effort, and resources of their fellow humans. Even when they are not stealing and killing, and even when they are cooperatively inclined, people understand that their interests seldom align in full with the interests of others, and that this might lead to conflict (Foster, 1965; Johnson et al., 2021; Różycka-Tran et al., 2015). Producers and consumers can benefit if they trade. But both might want to expand their surpluses at the expense of the other, and so they might be tempted to cheat. Men and women can benefit if they raise their children together. But they might be tempted to slack off when it comes to household chores, or to have affairs. Social conflict in exploitative and cooperative relationships would have been a major adaptive problem for our human ancestors.

Given this problem, natural selection would have selected for adaptations in the victim, the victim's associates, and (more variably) third parties to minimize the exposure to and the incurrence of the attendant costs. Indeed, the human mind-brain appears to be equipped with a suite of conceptual, decisional, evaluative, and motivational adaptations designed to deal with cost-imposing offenders: to avoid them, to deter them, to reform them, to incapacitate them, or to eliminate them. The interaction between these adaptations and local information inputs gives rise 
to human intuitions about justice: intuitions about what counts as a wrongful act, how wrongful acts should be dealt with, etc. Justice intuitions, in turn, form the core of justice-making institutions - a core that is augmented by deliberation and reflection (Sunstein, 1999; Kahan, 2015; see Sperber, 1997; Mercier \& Sperber, 2011; Greene et al., 2004; Guzmán et al., under review) and technologies such as writing (Fridman, 1985; Goody, 1986). This constitutes an adaptationist (aka naturalist) theory of justice-making institutions (Cosmides \& Tooby, 2006; Jones, 2001; Jones \& Goldsmith, 2005; Lieberman \& Patrick, 2018; Locke, 1988; Patrick, this issue; Patrick, 2016; Robinson et al., 2007; Robinson \& Kurzban, 2007; Sznycer \& Patrick, 2020).

Social conflict far predates the hominin lineage, and so do justice intuitions. In non-human species, might makes right. The spoils typically go to those with higher formidability and to those who most value the contested resource (Clutton-Brock \& Parker, 1995; Hammerstein \& Parker, 1982; Huntingford \& Turner, A, 1987) — although ability and willingness to deliver benefits are relevant in those non-human species that engage in cooperation and partner choice (Bshary \& Grutter, 2002; Raihani et al., 2010).

Might makes right in humans too (Sell, Tooby, et al., 2009; Cheng et al., 2013; von Rueden et al., 2008; Sell, Cosmides, et al., 2009; Sell et al., 2010; but see Lukaszewski et al., 2015; Durkee et al., 2020). However, social evolution in humans was characterized by a much greater emphasis on cooperation. Cooperation and the entry into the cognitive niche-characterized by language, causal intelligence, mind-reading, common knowledge, and cumulative culture (DeVore \& Tooby, 1987; Pinker, 2010) — gave humans a wealth of productive activities not generally available to non-human animals: care of offspring by mothers, fathers, and alloparents, local and regional trade, development and intergenerational transmission of complex technologies, buffering of ecological risks through food sharing and helping of the sick, cooperative hunting, and others (Boyd et al., 2011; De Freitas et al., 2019; Hill \& Hurtado, 1996; Kaplan et al., 2000; Tomasello, 2011). The great demographic and geographic expansion of humans from its African origins was enabled by this constellation of traits (Hamilton et al., 2009; Kaplan et al., 2000). Concomitantly with this productivity, however, newfound opportunities appeared for humans to exploit others, or to ruin others' investments or acquisitions through error or recklessness (see Allen \& Barzel, 2011). In this way, the brain may have evolved the suite of adaptations that produce the characteristic human sense of justice.

To be cost-effective, human justice intuitions must incline the actor to produce responses (e.g., withdrawal of cooperation, aggression) that are sufficiently powerful to deter offenders from offending but not so powerful that the potential future contributions of an offender are lost or that the offender view the response as a new offense that merits its own punishment (Petersen, Sell, et al., 2012; Sznycer \& Patrick, 2020). To balance these conflicting demands, justice intuitions must rely on exact estimates of the social value of specific others (referenced to the actor) based on the characteristics, actions, and inactions of others. Furnished with accurate social value information, the actor's justice intuitions, and the behavior that result from said intuitions, can be tailored to the costs imposed by the offender. Note that in addition to, and somewhat independent of, the quantitative matching of justice intuitions to the cost imposed by the offender, the mind appears to also carry out different types of tactics that are differentially well-suited to $(i)$ reform offenders, when they are deemed valuable and reformable, and to ( $i i)$ isolate, depower, or eliminate offenders or antagonists, when they are deemed irreformable or of low or negative association value (Petersen, Sell, et al., 2012). The first type of tactics has been traced to the anger system; the second type to hatred (Halperin et al., 2011; Sell, 2012; Sell et al., 
2021; Sell \& Lopez, 2020; Sell \& Sznycer, in press; Sznycer et al., in press) and other mechanisms such as envy (Pedersen et al., 2013; Zizzo \& Oswald, 2001; Sznycer et al., 2017; Lin \& Bates, 2021; see also Herrmann et al., 2008; Dawes et al., 2007; Raihani \& McAuliffe, 2012).

For example, the social value a focal individual imputes to individual $\mathrm{X}$ needs to decrease when, e.g., $\mathrm{X}$ takes a resource from the focal individual. But that decrease needs to be attenuated when, e.g., the taking is due to acute need and thus does not necessarily imply low valuation of the focal individual on X's part (Sell et al., 2017), or when the focal individual's claim to ownership is weak to begin with (see Boyer, 2015; Nancekivell et al., 2019; Rochat et al., 2014). In turn, the social value imputed to $X$ would inform the focal individual's justice intuitions with respect to $X$, such as the focal individual's desire that $X$ be punished (Sznycer \& Patrick, 2020; Tooby et al., 2008). In this way, accuracy in how people impute social value to other people enables justice intuitions to be cost-effective by defending against offenders neither too forgivingly nor too punitively.

Theories of selection pressures, including kin selection (Hamilton, 1964), reciprocation (Trivers, 1971), reputation (Nowak \& Sigmund, 1998), risk pooling (Cashdan, 1985; Kaplan \& Hill, 1985), externality management (Tooby \& Cosmides, 1996), and the asymmetric war of attrition (Hammerstein \& Parker, 1982), as well as evidence from psychology, neuroscience, animal-behavior, and cross-cultural studies (Buss, 1989; Lieberman et al., 2007; Fiske et al., 2007; Hare et al., 2010; Klein et al., 2008; Leary \& Baumeister, 2000; Sznycer, Xygalatas, et al., 2018; Sznycer, Al-Shawaf, et al., 2017; Sznycer, Xygalatas, Alami, et al., 2018; Durkee et al., 2019; Fareri et al., 2015), are converging to suggest that the mind includes specialized procedures that input information about the actions of others (e.g., contributes to collective action), the characteristics of others (e.g., generous, high-status), and the resources transacted by others (e.g., steals berry, steals eland carcass), and output accurate estimates of the prospective contributions, positive or negative, to the welfare of the valuer by specific others-i.e., accurate representations of the social value of specific others to the self. Internal estimates of the social value of others are transmitted to multiple mechanisms, including the mechanisms that produce justice intuitions: social evaluations, moral judgments, decisions to punish or reward, and offense-relevant emotions (Tooby et al., 2008; Delton \& Robertson, 2016; Petersen, Sell, et al., 2012; Sznycer et al., 2021; Sznycer \& Patrick, 2020). For example, both $(i)$ the social value imputed to individual X qua producer of food item $\alpha$ and ( $i$ i) the anger aroused if X steals food item $\alpha$ from the focal individual, track the nutrient content of food item $\alpha$ (Sznycer, under review).

The adaptationist theory of justice-making institutions is supported by various lines of evidence. For instance, justice intuitions seem a necessary precursor, evolutionarily and ontogenetically, for the emergence of laws against wrongdoing. Non-human animals lack laws but can display justice intuitions. For instance, when cheaters are punished (Bshary \& Grutter, 2002; Clutton-Brock \& Parker, 1995). Likewise, children have complex intuitions about wrongful acts, desert, and punishment before they can reason deliberatively, about the law or in general (Hamlin et al., 2011; McAuliffe et al., 2015; Rossano et al., 2011; Smetana, 1981). Further, there are human populations with justice intuitions and laws, and with justice intuitions but no (written) laws; in contrast, populations with laws but without justice intuitions do not seem to exist.

Also consistent with the adaptationist theory are distinctions apparent in both everyday behavior and legal codes. For example, the contrast between predatory harms and reactive harms 
is seen both in everyday thought and behavior (Hamlin et al., 2011; Wrangham, 2018) and in the legal tradition of treating premeditated offenses more seriously than offenses stemming from provocation (Patrick \& Lieberman, 2017). Also, laypeople perceive harms as graver when harms are imposed intentionally than when they are unintentional (Cushman, 2008; Sell et al., 2017). Echoing this contrast, judges (Kneer \& Bourgeois-Gironde, 2017) and legal codes worldwide treat harmful outcomes more harshly when they are imposed intentionally (Mikhail, 2009). Intriguingly, it has been argued that some populations, because of their cultural norms, are an exception to the general pattern of imputing more moral wrongness to those offenses that are intentional (Barrett et al., 2016). However, the exception claim has itself been questioned recently: Intentionality blindness in moral judgment seems a function of context more than culture (Barrett \& Saxe, 2021; see also Giffin \& Lombrozo, 2016; Young \& Saxe, 2011).

Further supporting the adaptationist theory is evidence indicating that laypeople across countries agree in their perceptions of how morally wrong different offenses are (Evans \& Scott, 1984; Newman \& Wolfgang, 2017; Robinson \& Kurzban, 2007; Stylianou, 2003). Moreover, lay justice intuitions ordinally match the punishments that legal codes (Robinson et al., 2010) and judges (Kääriäinen, 2018) stipulate for different offenses.

The adaptationist theory has been critiqued, however. The counter-claim is that "intuitions of justice are characterized by immense cultural heterogeneity" (Braman et al., 2010 p. 1604). Because of this heterogeneity, critics have argued that laws about wrongdoing can be more readily understood as originating from culture-specific social norms (Braman et al., 2010; Saguy \& Stuart, 2008). Under this alternative, realist theory of justice-making institutions, justice intuitions and criminal laws can differ across cultures massively, because the social norms that underlie intuitions and laws can differ across cultures massively.

In truth, justice intuitions, and criminal laws, can and do vary greatly in space and time (Barrett et al., 2016; McNamara et al., 2019; Nelken, 2011; Pinker, 2011), as realist theorists note. For example, blasphemy, selling alcohol, selling gum, homosexuality, mixed-raced marriage, divorce, and polygamy have been variously considered moral or immoral, legal or illegal, in different times and places. Furthermore, major changes in social norms, justice intuitions, and criminal laws are known to have occurred swiftly-orders of magnitude faster than natural selection can build complex adaptations (Allen \& Barzel, 2011; Inglehart, 2008; Inglehart et al., 2017). If natural selection cannot cause these changes, then culture and norms must be responsible, according to the realist theory.

However, an alternative account of this cultural variation in norms, and in what is considered immoral and sanctioned as illegal, is that $(i)$ cognitive mechanisms, including those that deliver justice intuitions, can incorporate both universal principles and parameters open to local information, and ( $i i)$ the variable outputs of such mechanisms could give rise to heterogeneity in manifest culture, in justice intuitions, and in criminal laws (Cosmides \& Tooby, 2006; Tooby \& Cosmides, 1992; see Mikhail, 2007), the way a Universal Grammar can give rise to diversity in languages (Chomsky \& Lasnik, 2008; Pinker, 2003).

The principle/parameter adaptationist hypothesis is suggested by the fact that the complex psychology underlying justice intuitions appears to be a species-wide trait despite sexual recombination and interbreeding between human groups (Tooby \& Cosmides, 1990). The principle/parameter adaptationist hypothesis is suggested also by the fact that experimenters can systematically shift the justice intuitions of individuals within a population by manipulating taskrelevant variables (e.g. Awad et al., 2020; Burnstein et al., 1994; Cushman, 2008; Liberman et al., 2004; O’Neill \& Petrinovich, 1998). These manipulated, within-culture shifts are often 
similar across cultures (Liberman et al., 2004; O’Neill \& Petrinovich, 1998; but see Robbins et al., 2017). Notably, modifications in task instructions or content can produce virtually instantaneous, reversible, within-individual changes in justice intuitions with effect sizes similar in size to what is often attributed to cultural norms (Nettle \& Saxe, 2020; Yamagishi et al., 2008). For example, there is more support for social welfare in Denmark than in the United States. But this difference disappears when participants consider specific cases with relevant background information: When asked about a welfare recipient who is a victim of bad luck (lazy), Danes and Americans express similarly high (low) support for welfare (Aarøe \& Petersen, 2014; see also Yamagishi et al., 2008). Clearly, these within-group shifts cannot be caused by between-group differences in norms.

Therefore, cultural heterogeneity, by itself, is insufficient to arbitrate between adaptationist and realist accounts of justice-making institutions.

Thus, there remain (at least) two candidate answers to the question over the origins and nature of justice-making institutions: (i) variable, culture-specific social norms, as hypothesized by the realist theory; and (ii) local conditions interacting with the open parameters of a socialevaluative psychology that is otherwise universal, as hypothesized by the adaptationist theory.

Unfortunately, in past studies, the study participants, the offenses rated by the participants, and the punishments stipulated by law for those offenses were sampled from modern masssocieties linked by commerce, tourism, and real-time communication technologies. Thus, the origin of justice-making institutions remains an open question. On the one hand, the crosscultural agreement in how laypeople, judges, and laws view offenses is insufficient to rule out the realist hypothesis - because the cross-cultural agreement might simply reflect study participants' cultural familiarity with the laws and norms that make up the study materials. And reciprocally, cultural heterogeneity in justice intuitions and laws is insufficient to rule out the adaptationist hypothesis, if this heterogeneity reflects variation in parameter settings and/or inputs in a cognitive architecture with universal structure.

One way out of the stalemate is to find out whether laypeople who lack explicit knowledge about the criminal laws of culturally unfamiliar societies can nevertheless intuitively recreate those laws in their essentials. If yes, that would buttress the adaptationist hypothesis and weaken the realist hypothesis. If not, that would buttress the realist hypothesis and weaken the adaptationist hypothesis.

Recently, Sznycer and Patrick (2020) have conducted tests with those characteristics. Can laypeople intuitively recreate criminal laws from societies that are radically culturally foreign? This question can help us identify which model better fits the data (the relationship between lay justice intuitions and criminal laws) when the data are unconfounded (when lay raters are culturally unfamiliar with the laws they evaluate). The adaptationist hypothesis predicts 'yes,' because it assumes there is enough invariant structure in the cognitive architecture that spawns justice intuitions - the hypothesized core of justice-making institutions.

Sznycer and Patrick (2020) also asked a second question: Do different types of justice intuitions covary in direction and intensity with one another from one offense to the next? The mind-brain generates multiple types of intuitions relevant to justice and conflict. Some of these intuitions lead to different goals and behaviors, even ones working at cross-purposes. For example, a victim's goal to punish an offender may be frustrated if the offender conceals his identity in shame. And yet, there are important reasons why those different types of intuitions might nevertheless vary in intensity in sync with one another. 
To see why, consider that social conflict sorts people into various roles: victim, offender, antagonist, ally of victim, ally of offender, bystander, mediator, group leader, lawmaker, and so on. Consider also that what counts as a best-response in an offense situation (e.g., offender assaults victim), or more generally in a conflict situation (e.g., lessor and lessee bargain over property damage of unclear origin), sensitively depends on the role the focal individual is acting out (Tooby \& Cosmides, 2010). For example, if someone steals something from someone else on the assumption that the benefit to be realized from the theft will outweigh the cost of being devalued by others (weighted by the odds of being detected), then that person will steal when conditions are auspicious (e.g., when no one is watching), and propitiate the victim in shame if and when she is detected (Keltner et al., 1997; Weisfeld \& Dillon, 2012). Meanwhile, victims must down-regulate the social value they impute to offenders to echo the now costlier prospects of interacting or being associated with them. Third-parties must display fairness by condemning the offender on the particulars of the offense (Baumard et al., 2013; Shaw, 2013). And legislators must make laws competently; for instance, by matching punishments to offenses in a manner that the public deems just. In sum, an offense may elicit many different responses depending on what role the individual is playing in the offense (and other variables).

There are major differences between judging an offense in terms of its moral wrongness, hiding in shame because one committed an offense, devaluing and punishing an offender, and legislating by matching offenses to punishments ex-ante. And yet, these various judgments, decisions, emotions, and behaviors, if they are to be calibrated in Goldilocks fashion-neither excessively nor insufficiently - all need to accurately reflect the social value of the offender given the acts of offenders (e.g., theft, murder) - and given a host of additional variables relevant to social value computation: the degree to which the offender desired to harm (Cushman, 2008), the degree to which the offender had ex-ante beliefs or knowledge that harm might occur (Cushman, 2008), the degree to which the harm was aimed at a specific victim (A. Sell et al., 2017), the presence or absence of mitigating circumstances (Barrett et al., 2016), relational and personal characteristics of offender and victim (Devine \& Caughlin, 2014; Lieberman \& Linke, 2007; Stevenson et al., 2009), the degree to which the action or inaction is locally moralized even when harm is absent (Graham et al., 2009; Young \& Saxe, 2011), ecological circumstances (Williams et al., 2019), and so on.

Participants in the Sznycer and Patrick (2020) studies read between 20 and 30 offenses drawn from one of three legal codes: one from the United States, a culture that is familiar to the participants (Title 18 (Crimes and Offenses) of the Consolidated Pennsylvania Statutes; hereafter, Title 18), and two from culturally unfamiliar societies remote in space and time: The Laws of Eshnunna (Mesopotamia, ca 1770 BCE; Roth et al., 1997) and the Tang Code (China, 635 CE; Johnson, 2014).

The stimuli conveyed the offenses simply and succinctly, in English, while preserving the basic characteristics of the offenses as featured in their corresponding statutes. Participants were shown the 20-30 offenses but not the punishments dictated by law for those offenses. The stimuli included offenses such as: rape, voluntary manslaughter, robbery, arson, incest (Title 18); causing someone's death in a brawl, biting out the eye of another man, deflowering the slave of another person, fraudulently seizing a boat, failing to keep one's aggressive ox in check (Laws of Eshnunna); killing a person in a fight, killing one's slave even though he has not committed an offense, beating an elder sibling, violating curfew, killing government cattle (Tang Code).

Participants were assigned to one of five "role" conditions in a between-subjects design: time, money, moral wrongness, devaluation, or shame. In the time and money conditions, 
participants were asked to imagine they are lawmakers and, for each offense, to legislate the sentence (in number of years in prison) or monetary fine, if any, those offenses should be punished with by law. In the moral wrongness condition, participants were asked to rate how morally wrong those offenses are. In the devaluation condition, participants were asked to rate how negatively they would view another individual if that individual committed those offenses. In the shame condition, participants were asked to rate how much shame they would feel if they committed those offenses. Other than these differences reflecting perspective and measure (e.g., intensity of shame in the shame condition; years in prison in the time condition), the offenses were the same across conditions. There were 15 conditions in total $(3$ legal codes $\mathrm{x} 5$ role conditions).

Because the prediction is that laypeople can recreate culturally unfamiliar laws absent explicit knowledge of law (in general) or the laws making up the stimuli (in particular), participants were excluded from analyses if they reported having college-level education in law or if they correctly identified the legal code from which the offenses were drawn. To incentivize correct identifications, participants received a bonus for correct answers in addition to their participation fee. For replication purposes, the study was conducted with participants from two national cultures, the United States and India. Predictions, stimuli, analyses, and exclusion criteria were preregistered before data collection began (https://aspredicted.org/c2mq7.pdf; https://aspredicted.org/zv5hp.pdf; https://aspredicted.org/a42gv.pdf).

The data indicated that different types of justice intuitions covary in direction and intensity with one another from one offense to the next. Offenses rated high on moral wrongness tended to also be rated high on devaluation, shame, time (in prison), and money (fine). How is this coordination across responses achieved? Parsimony suggests that devaluation, shame, judgments of moral wrongness, mock-lawmaking, and perhaps other types of offense-related responses rely on a common set of evaluations - although the data cannot rule out convergence across responses through independent value computation by each response. The mind might impute a specific (negative) value to, for example, the action "killing" (and/or its variously parameterized instances; e.g., "premeditated killing of stranger", "accidental killing of medicine man"), and this value might be transmitted to and used by a host of other mechanisms which would deliver their specific responses based (in part) on the value of "killing" at the source: the moral wrongness imputed to the act of killing, the intensity of felt shame if one killed, the grading of "killing" if one is a lawmaker making law, and so on.

The data also showed that participants recreated, at least skeletally, laws given the offense descriptions provided to them. Participants could intuit laws from a modern, culturally familiar society (United States' Title 18). Specifically, in each of the five conditions - time, money, moral wrongness, devaluation, and shame - and in the two countries where the study was conducted - the United States and India - there were positive correlations between participants' ratings of the offenses and the actual punishments dictated by Title 18 for those offenses. This finding agrees with previous evidence showing that laypeople echo legal codes from familiar cultures in how offenses are punished.

Critically, participants intuitively recreated criminal laws from radically culturally unfamiliar societies - ancient Mesopotamia (Laws of Eshnunna) and ancient China (Tang Code). Strikingly, all 20 correlations ( 2 participant countries x 2 ancient legal codes $\mathrm{x} 5$ role conditions) between participants' ratings and actual legal punishments had a positive sign, and 18 of these 20 correlations were significant $(p<.05)$. 
To be sure, the agreement in justice thinking between modern laypeople and ancient lawmakers was far from perfect. For example, the Tang item killing one's slave even though he has not committed an offense ${ }^{1}$ was considered a relatively mild offense by Tang lawmakers but a grave offense by American and Indian participants. Differences notwithstanding, there were substantial correspondences. For example, American and Indian participants echoed the Tang lawmakers' belief that beating and killing a person in a fight is a more serious offense than betting goods and articles in games of chance. This mix of cross-cultural similarities and differences is consistent with the principle/parameter adaptationist hypothesis. The universal principles may explain why participants generally saw eye to eye with the Tang lawmakers. The open parameters and variable inputs may explain the cultural variation.

The fact that lay justice intuitions can match laws from highly unfamiliar cultures agrees with the adaptationist account and raises questions regarding alternative realist hypotheses. For example, cultural inheritance from a common ancestor is unlikely. Also unlikely is convergent cultural evolution arising from similarities in ecology, religion, ideology, degree of market integration, or subsistence mode, because those variables vary massively across modern United States, modern India, Tang China (635 CE), and Eshnunna (ca 1770 BCE).

\section{Distributive justice}

Justice in the realm of distribution sometimes corresponds with justice in the realm of wrongdoing. If Jack acquires a resource by stealing it from Jill, or if Jack exempts himself from a communal duty by falsifying his medical record, Jack's advantage is due to Jack's wrongful action. However, people can consider it an injustice if some have "too much," or if some have "too little" (Kiatpongsan \& Norton, 2014; Norton \& Ariely, 2011; see Sznycer, Ermer, \& Tooby, 2018), even when wrongdoing is not a cause of the inequality - not only for the wrongdoing that can follow inequality (Daly et al., 2001; Wilson \& Daly, 1997) but for the inequality itself (Rawls, 1971).

Adaptationism can help us understand distribution-making institutions and the concept of justice in distributions: what counts as a fair or just distribution of goods, bads, rewards, punishments, duties, and privileges among individuals, social roles, and corporate groups; what counts as unfairness; what is to be done to prevent unfairness or to deal with unfairness; and so on (see Delton \& Sell, 2014).

Data from archaeology and contemporary human foragers suggest that our human ancestors evolved in ecologies featuring high mortality (Burger et al., 2012), scarcity (Hill \& Hurtado, 1996), high variance in food acquisition (Hill \& Hurtado, 1996; Kaplan \& Hill, 1985), high incidence of injury and disease (Sugiyama, 2004), and attacks by human and non-human predators (Keeley, 1997). These data also suggest that our ancestors acted to confront these ecological risks.

Although various strategies are possible to minimize risk - reducing one's exposure to risk, self-insurance, and risk pooling between individuals or households - risk pooling would have been a preferred solution given the ecological, social, and technological conditions of ancestral humans (Kaplan \& Hill, 1985; Wiessner, 1982; Winterhalder, 1986; Dorfman, 1998; Cronk et al., 2019). Indeed, humans in all foraging societies rely on fellow group members for the assistance necessary to defeat ecological risks, and mutual aid is believed to be a key aspect of

\footnotetext{
${ }^{1}$ Text of statute: "Article 321.2. - If a slave is killed who has not committed an offense, the punishment is one year of penal servitude." (W. Johnson, 2014 p. 354). NB: the servitude punishment is redeemable by paying a fine of 20 copper chin.
} 
human biology (Burkart et al., 2009; Clutton-Brock, 2009; Kaplan et al., 2000; Tomasello et al., 2012).

\subsection{Risk-pooling and compassion}

In risk-pooling, risks are pooled. If many individuals are exposed to risk independently, then losses, although individually unpredictable, are collectively predictable. And the individuals can reduce their variance in consumption if they trade predictable, small losses for unpredictable and potentially catastrophic losses - the kinds they may incur if they are not part of a risk-pooling system (Cashdan, 1985). In risk-pooling, resources (e.g., the $40^{\text {th }}$ pound of meat) move from where their subjective marginal value is low to where their subjective marginal value is high, and accrue a social obligation in the minds of beneficiaries which donors feel entitled to when the roles are reversed.

Risk-pooling is enabled by a specialized psychology which, among other things, generates powerful justice intuitions: For example, intuitions regarding when to share, and when to demand that others share. It has been argued that the institution of progressive, governmentenacted redistribution can be traced to this type of intuitions (Cosmides \& Tooby, 2006). From this perspective, $(i)$ the poor's feeling that they deserve help, (ii) the wealthy's feeling that they are willing to be taxed in order for the needy to be helped, and (iii) the notion that it is just for the government to transfer resources from the wealthy to the poor are generated by an ancient psychology for pooling risks when this psychology encounters its activating inputs in modern environments (see, e.g., Aarøe \& Petersen, 2014; Delton et al., 2018).

Various conditions are necessary for risk-pooling sharing to be an evolutionarily stable strategy.

First, there must be reciprocity. Those who had resources and helped the needy will expect to be helped when the roles are reversed. If there is no reciprocity, the motivation to share does not evolve (Trivers, 1971). Given this, adaptations would have evolved to detect cheaters, and to avoid, deter, and reform cheaters. There is now evidence of a specialized adaptation for detecting cheaters (Cosmides et al., 2005, 2010; Cosmides \& Tooby, 2015; Fiddick et al., 2000; Gigerenzer \& Hug, 1992; Maljkovic, 1987)_-individuals who gain by taking a benefit without satisfying the requirement the benefit is contingent on - which is part of a broader suite of adaptations for engaging in social exchange (Cosmides \& Tooby, 1989, 2005). This evidence is mostly about cheater detection in social exchanges for mutual benefit (e.g., in barter), although there is some evidence of cheater detection in risk-pooling contexts (Chang et al., 2015). Other evidence for reciprocity, from small-scale societies, indicates contingency in food sharing: The more A shares with B, the more B shares with A (Gurven, 2004; but see Kaplan \& Hill, 1985; Bird et al., 2002). In addition, evidence shows that when partners fail to reciprocate despite their ability to do so, people communicate their displeasure to them (e.g., with anger) and/or act to lower their payoffs ("punishment"). Both punishment (Balliet et al., 2011; Masclet et al., 2003) and communication (Masclet et al., 2003) deter cheating (see Xiao \& Houser, 2005).

Interestingly, mere ex-ante knowledge that others have the option to punish (Balliet et al., 2011; Fehr \& Gächter, 2000) or to gossip to third parties (Wu et al., 2016) is often sufficient to deter cheating (see Sznycer et al., 2016; Sznycer, Xygalatas, et al., 2018; Van Der Schalk et al., 2012).

Second, outcomes must be based on chance more than on effort or skill (Kameda et al., 2003; Kaplan \& Hill, 1985; Tooby \& Cosmides, 1992). Buying insurance (e.g., sharing in the context of a risk-pooling agreement) is more economically efficient when shortfalls are unpredictable and serious, and less efficient when shortfalls are predictable. Further, requests for 
help, while expected in risk-pooling, indicate exploitative motives on the requester's part when the corresponding shortfall is due to insufficient effort. This would have shaped a psychology that is inclined to share when a shortfall is due to bad luck, and to not share otherwise - and especially not when the shortfall results from the intentional withholding of effort (Delton et al., 2012). For instance, a target's failure to acquire food elicits much more benevolent and generous responses from people if the target foraged but failed to obtain food than if the target simply did not bother foraging (Delton et al., 2012, study 2). In contrast, if the target does put in work, people respond with similar benevolence whether the target acquires food or not (e.g., target finds food, then accidentally loses it; Delton et al., 2012 study 3; see also Delton \& Robertson, 2012). Relatedly, data from the U.S. and Japan show that haves are more willing to share with have-nots, and have-nots are more willing to demand that haves share with them, when the resource is described as a windfall (versus due to effort; Kameda et al., 2002). In an experiment on foraging in a virtual environment with no external enforcement of sharing other than participants' incentives to maximize their own food consumption, food sharing increased in a high-mean, high variance condition (where luck plays a major role), but remained infrequent in a low-mean, low-variance condition (where luck plays a lesser role; Kaplan et al., 2012, see also Kaplan et al., 2018). Under the logic of risk-pooling, denying help to victims of bad luck and extending help to free-riders are injustices.

Third, failure must be unsynchronized across economic units (e.g., households) such that reversals are common across units (Campenni et al., 2017). If all the units fail at the same time, there are no haves who could share with the have-nots.

Fourth, resources must occur in packages big enough that consumption by the producer and his family yields decreasing marginal returns. Among human foragers, resources that occur in large packages and with high variance, such as big game, are shared more extensively than other types of resources, such as plant foods (Gurven, 2004; Kaplan \& Hill, 1985; Lee, 1979). A similar pattern is observed among non-human primates (Strum, 1981).

A large body of research shows that features of risk-pooling psychology are seen in citizens' attitudes about progressive redistribution. The focus of this work has been on the desirability of redistribution as a function of the causes of bad outcomes.

People tend to support government transfers to the poor when the poor's predicament is described as being due to bad luck. In contrast, people oppose those transfers when the poor are described as unwilling to put in effort (Williamson, 1974; Petersen, Sznycer, et al., 2012; Aarøe \& Petersen, 2014; Gee et al., 2017; see also Gilens, 2009). This "deservingness heuristic" (Petersen, 2015) is seen across cultures: World Values Survey data indicate that individuals ( $\mathrm{N}=$ 59,144 ) who perceive poverty as being due to laziness (versus unfair society) are more likely to oppose government transfers to the poor; this correlation is observed in 48 of the 49 countries for which data exist (Petersen, Sznycer, et al., 2012).

The distinction between free-riders and victims of bad luck is deep-seated: In a memory confusion paradigm (Taylor et al., 1978), when facing worse-off targets described as either freeriders or unlucky (evolutionarily ancient distinction) in the context of either an interpersonal interaction or social welfare (evolutionarily novel distinction; $2 \times 2$, factorial design), categorization by underlying motive is greater than categorization by context, both in the United States and Denmark (Petersen, 2012). Relatedly, cues of the extent to which a welfare recipient is actually deserving (e.g., young man versus injured woman) predicts support for welfare to a greater extent than does blanket endorsement of egalitarianism values (Petersen et al., 2011), 
degree of political sophistication (Petersen et al., 2011), or national-cultural differences concerning welfare attitudes (Aarøe \& Petersen, 2014).

Nation-level differences in support for welfare may themselves stem from national differences in the motivations that people impute to welfare recipients. Consistent with this possibility, nation-level social spending (corrected for GDP) is positively associated with the nation-level belief that income is determined by luck (Alesina et al., 2001; Aarøe \& Petersen, 2014) - although other factors have been put forth as well to explain national differences in social spending (e.g., racism (Alesina et al., 2001; Gilens, 2009); ideology (Sears et al., 1980)).

Support for redistribution is sometimes attributed to a taste for fairness (Alesina \& Angeletos, 2005; Tyran \& Sausgruber, 2006). However, the findings above suggest instead that support for redistribution is motivated by feelings of compassion toward the needy, where the scope of compassion is dictated by the psychology for risk-pooling. Note that the term "fairness" is used to refer to many different concepts - low variance in outcomes (Fehr \& Schmidt, 1999); uniformity in the application of rules or standards (Baumard et al., 2013; Shaw \& Olson, 2014; Thibaut et al., 1974); proportionality between payoff on the one hand and effort, skills, economic output, seniority, need, or social status on the other hand (Hook \& Cook, 1979; Hundley \& Kim, 1997; Liénard et al., 2013); the availability of institutional safeguards against risk (Rawls, 1971), and others - and the taste for "fairness" variously defined has little or no effect on attitudes about redistribution when discrete, well-defined motives (e.g., compassion) are allowed as predictors (Sznycer et al., 2017).

Support for redistribution is sometimes construed as a unitary issue. However, the preceding argument suggests instead that multiple motivational systems may make redistribution appealing (or unappealing). From the standpoint of event description, various things happen in progressive redistribution in the short term, including: ( $i$ ) the worse-off gain resources; $(i i)$ the better-off lose resources; (ii) the government manages the transfers (it taxes, it subsidizes, it keeps resources for its own operation, it punishes tax evasion, etc.). The conceptual representation of each type of event, and the subjective value imputed to each type of event, may differ from one individual to the next and, within individuals, from one motivational system to the next (Is taxation theft? Is social welfare just?). Further, a given type of event may be wished for or liked or disliked by each of various individuals or motivational systems, but for different reasons.

\subsection{Self-interest}

Adding to the welfare of the needy is one motive. But individuals are also designed to attach value to their own welfare and the welfare of their families, and the self-interest is another motive. The self-interest will limit how much an individual will sacrifice in order to dampen others' shortfalls. The self-interest can also motivate the selfish taking from others, needy or not, if the taking can be done in stealth or if the taker is sufficiently powerful to dictate the terms of the interaction (Charness \& Rabin, 2002; Petersen et al., 2013; Price et al., 2017). In the realm of mass politics, self-interest provides some of the impetus for supporting redistributive transfers when the individual expects to profit from it (Hasenfeld \& Rafferty, 1989; Jakobsen \& Listhaug, 2012; Lin \& Bates, 2021; Sznycer et al., 2017; Tullock, 1983).

Both the self-interest and compassion can motivate support for redistribution. But these motivations have distinctive signatures. For example, donations of one's own resources to the poor (as distinct from support for progressive, government-enacted redistribution) is uniquely predicted by compassion but not the self-interest. This has been observed in samples from three countries (Sznycer et al., 2017). 


\subsection{Envy}

Envy is yet another possible motive for redistributionist policies. Harming the better-off is a side-effect of compassion (or self-interest), when the goal is benefitting the poor (or the self). In envy, in contrast, harming the better-off is the good itself (Foster, 1965; Schoeck, 1987).

Envy can be inferred in small groups, where people spend their own money in order to burn the money of others, in particular the wealthier others (Dawes et al., 2007; Pedersen et al., 2013; Zizzo \& Oswald, 2001). Envy can be inferred in the workplace, where job satisfaction decreases not on low absolute incomes but on low incomes relative to the reference class of rivals - the subset of fellow workers with similar qualifications (Clark \& Oswald, 1996; see also Easterlin, 1974). Envy can also be inferred in farming villages, where individuals with envious neighbors innovate less, perhaps out of fear of the evil eye - the ill-will one may arouse if innovation leads to higher yields (Kebede \& Zizzo, 2011; Schoeck, 1987). And although positional arms races destroy welfare in the keeping up with the Joneses equilibrium (Frank, 2005), the fear of envy equilibrium results in even lower aggregate welfare (Gershman, 2014).

The usefulness of envy may be limited in modern economies, however. Damage to the better-off yields a good in positional, zero-sum games, where consumption by others comes at the expense of one's own consumption (Różycka-Tran et al., 2015; Sznycer et al., forthcoming). For example, goods such as food become positional goods when they are scarce relative to the number and need level of consumers. The payoff for mobilizing envy, therefore, may have been higher in ancestral economies of scarcity and limited-productivity, and in agrarian economies where self-insurance is viable (e.g., by storing grain; Foster, 1965), and lower in modern, highproductivity economies. On the other hand, some have argued that envy flourishes when free markets are combined with the leveling force of democracy (Tocqueville, 2003; Chua, 2004). Indeed, envy seems to be alive and well in modern societies (Appel et al., 2016; Charness \& Rabin, 2002; DelPriore et al., 2012; Fiske, 2011; Smith \& Kim, 2007), perhaps because humans have spent too few generations in high-productivity economies for natural selection to edit out the envy system. Further, status is inherently a positional good, and so envy over status might be selected for whether the productivity of the economy is low or high.

In sum, envy might play a role in progressive redistribution by making it appealing to see a diminishment in the welfare, power, or status of the better-off. What role, if any, envy plays in redistribution remains to be determined, however - although various conjectures have been offered on envy and redistribution (Rawls, 1971; Tullock, 1983; Von Mises, 1951).

Recently, this question has begun to be addressed empirically. In a set of studies, dispositional envy predicted support for progressive redistribution, statistically controlling for dispositional compassion, expectations of personal profit from redistribution, and demographic variables. The unique effects of envy were modest but reliable across four national samples: the US, the UK, India, and Israel (Sznycer et al., 2017; see also McClendon, 2012). Unique effects of envy were observed also in nine additional samples from the United States (Sznycer et al., 2017, studies 2a-c, S1a-b, and S2a-d). Support for progressive redistribution through envy has a characteristic signature: Envy, but not compassion or the self-interest, predicts a desire to heavily tax the wealthy even when that results in relatively less money for the poor (Sznycer et al., 2017; see also Wobker, 2015). More recently, Lin and Bates (2021) have reported unique effects of envy in samples from the UK. They found that malicious envy, but not benign envy or dispositional envy, predicts support for redistribution. Meanwhile, (Hansen, under review) found unique negative effects of envy of the rich on opposition to taxing the rich (more envy of the 
rich, less opposition to see the rich taxed); she found this in two American samples and one Danish sample - two of the three samples were nationally representative.

\section{Concluding remarks}

From a descriptive standpoint, institutions appear to implement and enforce social norms: grouplevel rules or standards in mixed-motive situations that are known to individuals, and that individuals would rather conform to if they believed that a sufficiently large proportion of other individuals conform to and expect the individual to conform to (Bicchieri, 2005). These formal or informal rules of the game (North, 1990) reduce transaction costs and can further cooperation and commons management (Ostrom, 1990). Norm-based accounts of institutions are intuitive and observationally adequate. But those accounts do not constitute causal explanations of why norms and institutions exist as quasi-stable entities; why different games call for different norms and institutions; why some norms and institutions are intuitive, compelling, and widespread in space and time whereas others are unintuitive, odious, and rare; and so on (Tooby \& Cosmides, 1992; Boyer \& Petersen, 2012; Boyer, 2018; Sperber, 1996; Fiddick, 2008; Sznycer, 2019). Thus, norm-based renditions need to be supplemented with causal explanations. Here, we have argued that adaptationism can supply at least some of the requisite explanations. We have argued that justice-making institutions originate in adaptive problems relevant to social conflict, and in the conceptual, motivational, and decision-making adaptations those adaptive problems have shaped over evolutionary time. Much data suggests that adaptationism is a promising framework for understanding human institutions. The true extent to which this framework can explain the origins, structure, and cultural and historical distribution of justice-making and other human institutions remains to be determined.

Acknowledgements: We thank Carlton Patrick for helpful comments.

\section{References}

Aarøe, L., \& Petersen, M. B. (2014). Crowding out culture: Scandinavians and Americans agree on social welfare in the face of deservingness cues. The Journal of Politics, 76(3), 684697.

Alesina, A., \& Angeletos, G.-M. (2005). Fairness and redistribution. The American Economic Review, 95(4), 960-980.

Alesina, A. F., Glaeser, E. L., \& Sacerdote, B. (2001). Why doesn't the US have a Europeanstyle welfare system? National bureau of economic research Cambridge, Mass., USA.

Allen, D. W., \& Barzel, Y. (2011). The evolution of criminal law and police during the premodern era. The Journal of Law, Economics, \& Organization, 27(3), 540-567.

Appel, H., Gerlach, A. L., \& Crusius, J. (2016). The interplay between Facebook use, social comparison, envy, and depression. Current Opinion in Psychology, 9, 44-49.

Awad, E., Dsouza, S., Shariff, A., Rahwan, I., \& Bonnefon, J.-F. (2020). Universals and variations in moral decisions made in 42 countries by 70,000 participants. Proceedings of the National Academy of Sciences, 117(5), 2332-2337.

Balliet, D., Mulder, L. B., \& Van Lange, P. A. (2011). Reward, punishment, and cooperation: A meta-analysis. Psychological Bulletin, 137(4), 594-615.

Barrett, H. C., Bolyanatz, A., Crittenden, A. N., Fessler, D. M., Fitzpatrick, S., Gurven, M., Henrich, J., Kanovsky, M., Kushnick, G., \& Pisor, A. (2016). Small-scale societies 
exhibit fundamental variation in the role of intentions in moral judgment. Proceedings of the National Academy of Sciences, 113(17), 4688-4693.

Barrett, H. C., \& Saxe, R. R. (2021). Are some cultures more mind-minded in their moral judgements than others? Philosophical Transactions of the Royal Society B, 376(1838), 20200288.

Baumard, N., André, J.-B., \& Sperber, D. (2013). A mutualistic approach to morality: The evolution of fairness by partner choice. Behavioral and Brain Sciences, 36(1), 59-78.

Bentham. (1907). An introduction to the principles of morals and legislation. Clarendon Press.

Bicchieri, C. (2005). The grammar of society: The nature and dynamics of social norms. Cambridge University Press.

Bird, R. B., Bird, D. W., Smith, E. A., \& Kushnick, G. C. (2002). Risk and reciprocity in Meriam food sharing. Evolution and Human Behavior, 23(4), 297-321.

Blackstone, W. (1765). Commentaries on the Laws of England. Clarendon Press.

Boehm, C. (1994). Blood revenge: The anthropology of feuding in Montenegro and other tribal societies. University Press of Kansas.

Bohannan, P. (2018). Justice and Judgment among the Tiv. Routledge.

Bowles, S., Choi, J.-K., \& Hopfensitz, A. (2003). The co-evolution of individual behaviors and social institutions. Journal of Theoretical Biology, 223(2), 135-147.

Boyd, R., Richerson, P. J., \& Henrich, J. (2011). The cultural niche: Why social learning is essential for human adaptation. Proceedings of the National Academy of Sciences, 108(Supplement 2), 10918-10925.

Boyer, P. (2015). How natural selection shapes conceptual structure: Human intuitions and concepts of ownership. The Conceptual Mind. New Directions in the Study of Concepts, 185-200.

Boyer, P. (2018). Minds make societies: How cognition explains the world humans create. Yale University Press.

Boyer, P., \& Petersen, M. B. (2012). The naturalness of (many) social institutions: Evolved cognition as their foundation. Journal of Institutional Economics, 8(1), 1-25.

Braman, D., Kahan, D. M., \& Hoffman, D. A. (2010). Some realism about punishment naturalism. The University of Chicago Law Review, 77(4), 1531-1609.

Bshary, R., \& Grutter, A. S. (2002). Asymmetric cheating opportunities and partner control in a cleaner fish mutualism. Animal Behaviour, 63(3), 547-555.

Burger, O., Baudisch, A., \& Vaupel, J. W. (2012). Human mortality improvement in evolutionary context. Proceedings of the National Academy of Sciences, 109(44), 18210 18214.

Burkart, J. M., Hrdy, S. B., \& Van Schaik, C. P. (2009). Cooperative breeding and human cognitive evolution. Evolutionary Anthropology: Issues, News, and Reviews, 18(5), 175186.

Burnstein, E., Crandall, C., \& Kitayama, S. (1994). Some neo-Darwinian decision rules for altruism: Weighing cues for inclusive fitness as a function of the biological importance of the decision. Journal of Personality and Social Psychology, 67, 773-789.

Buss, D. M. (1989). Sex differences in human mate preferences: Evolutionary hypotheses tested in 37 cultures. Behavioral and Brain Sciences, 12(1), 1-14.

Campenni, M., Cronk, L., \& Aktipis, A. (2017). Correlated disasters and need-based transfers: The limits of risk pooling systems in simulated ecologies. BioRxiv, 230607. 
Cashdan, E. A. (1985). Coping with risk: Reciprocity among the Basarwa of northern Botswana. Man, 20, 454-474.

Chang, A., Aktipis, A., \& Cronk, L. (2015). Cheater detection in need-based transfer systems. Poster Presented at the 27th Annual Human Behavior and Evolution Society Conference, Columbia, $M O$.

Charness, G., \& Rabin, M. (2002). Understanding social preferences with simple tests. The Quarterly Journal of Economics, 117, 817-869.

Cheng, J. T., Tracy, J. L., Foulsham, T., Kingstone, A., \& Henrich, J. (2013). Two ways to the top: Evidence that dominance and prestige are distinct yet viable avenues to social rank and influence. Journal of Personality and Social Psychology, 104(1), 103-125.

Chomsky, N., \& Lasnik, H. (2008). The theory of principles and parameters. In Syntax (pp. 506569). De Gruyter Mouton.

Chua, A. (2004). World on fire: How exporting free market democracy breeds ethnic hatred and global instability. Anchor.

Clark, A. E., \& Oswald, A. J. (1996). Satisfaction and comparison income. Journal of Public Economics, 61(3), 359-381.

Clutton-Brock, T. (2009). Cooperation between non-kin in animal societies. Nature, 462(7269), 51-57.

Clutton-Brock, T. H., \& Parker, G. A. (1995). Punishment in animal societies. Nature, 373(6511), 209-215.

Cosmides, L., Barrett, H. C., \& Tooby, J. (2010). Adaptive specializations, social exchange, and the evolution of human intelligence. Proceedings of the National Academy of Sciences, 107, 9007-9014.

Cosmides, L., \& Tooby, J. (1989). Evolutionary psychology and the generation of culture, part II : Case study: A computational theory of social exchange. Ethology and Sociobiology, 10, 51-97.

Cosmides, L., \& Tooby, J. (2005). Neurocognitive adaptations designed for social exchange. In D. M. Buss (Ed.), The Handbook of Evolutionary Psychology (pp. 584-627). Wiley.

Cosmides, L., \& Tooby, J. (2006). Evolutionary psychology, moral heuristics, and the law (G. Gigerenzer \& C. Engel, Eds.; pp. 175-205). MIT Press.

Cosmides, L., \& Tooby, J. (2015). Adaptations for reasoning about social exchange. In The Handbook of Evolutionary Psychology, Second edition. Volume 2: Integrations (D. Buss., Ed.) (pp. 625-668). John Wiley \& Sons. http://onlinelibrary.wiley.com/doi/10.1002/9781119125563.evpsych225/full

Cosmides, L., Tooby, J., Fiddick, L., \& Bryant, G. A. (2005). Detecting cheaters. Trends in Cognitive Sciences, 9, 505-506.

Cronk, L., Berbesque, C., Conte, T., Gervais, M., Iyer, P., McCarthy, B., Sonkoi, D., Townsend, C., \& Aktipis, A. (2019). Managing risk through cooperation: Need-based transfers and risk pooling among the societies of the Human Generosity Project. In Global perspectives on long term community resource management (pp. 41-75). Springer.

Curry, O. S., Mullins, D. A., \& Whitehouse, H. (2019). Is it good to cooperate? Testing the theory of morality-as-cooperation in 60 societies. Current Anthropology, 60(1), 47-69.

Cushman, F. (2008). Crime and punishment: Distinguishing the roles of causal and intentional analyses in moral judgment. Cognition, 108(2), 353-380.

Daly, M., \& Wilson, M. (1983). Sex, evolution, and behavior. Willard Grant Press Boston. 
Daly, M., Wilson, M., \& Vasdev, S. (2001). Income inequality and homicide rates in Canada and the United States. Canadian Journal of Criminology, 43, 219-236.

Dawes, C. T., Fowler, J. H., Johnson, T., McElreath, R., \& Smirnov, O. (2007). Egalitarian motives in humans. Nature, 446(7137), 794-796.

De Freitas, J., Thomas, K., DeScioli, P., \& Pinker, S. (2019). Common knowledge, coordination, and strategic mentalizing in human social life. Proceedings of the National Academy of Sciences, 116(28), 13751-13758.

DelPriore, D. J., Hill, S. E., \& Buss, D. M. (2012). Envy: Functional specificity and sexdifferentiated design features. Personality and Individual Differences, 53(3), 317-322.

Delton, A. W., Cosmides, L., Guemo, M., Robertson, T. E., \& Tooby, J. (2012). The psychosemantics of free riding: Dissecting the architecture of a moral concept. Journal of Personality and Social Psychology, 102, 1252-1270.

Delton, A. W., Petersen, M. B., DeScioli, P., \& Robertson, T. E. (2018). Need, compassion, and support for social welfare. Political Psychology, 39(4), 907-924.

Delton, A. W., \& Robertson, T. E. (2012). The social cognition of social foraging: Partner selection by underlying valuation. Evolution and Human Behavior, 33, 715-725.

Delton, A. W., \& Robertson, T. E. (2016). How the mind makes welfare tradeoffs: Evolution, computation, and emotion. Current Opinion in Psychology, 7, 12-16.

Delton, A. W., \& Sell, A. (2014). The co-evolution of concepts and motivation. Current Directions in Psychological Science, 23(2), 115-120.

DeScioli, P., \& Kurzban, R. (2013). A solution to the mysteries of morality. Psychological Bulletin, 139(2), 477.

Devine, D. J., \& Caughlin, D. E. (2014). Do they matter? A meta-analytic investigation of individual characteristics and guilt judgments. Psychology, Public Policy, and Law, 20(2), 109.

DeVore, I., \& Tooby, J. (1987). The reconstruction of hominid behavioral evolution through strategic modeling. The Evolution of Human Behavior: Primate Models, Edited by WG Kinzey, 183-237.

Dorfman, M. S. (1998). Introduction to risk management and insurance.

Dunlea, J. P., \& Heiphetz, L. (2020). Children's and adults' understanding of punishment and the criminal justice system. Journal of Experimental Social Psychology, 87, 103913.

Durkee, P. K., Lukaszewski, A. W., \& Buss, D. M. (2019). Pride and shame: Key components of a culturally universal status management system. Evolution and Human Behavior, 40(5), 470-478.

Durkee, P. K., Lukaszewski, A. W., \& Buss, D. M. (2020). Psychological foundations of human status allocation. Proceedings of the National Academy of Sciences, 117(35), 2123521241.

Durkheim, E. (1984). The division of labor in society. Free Press.

Dworkin, R. (1986). Law's empire. Harvard University Press.

Easterlin, R. A. (1974). Does economic growth improve the human lot? Some empirical evidence. In Nations and households in economic growth (pp. 89-125). Elsevier.

Evans, S. S., \& Scott, J. E. (1984). The seriousness of crime cross-culturally: The impact of religiosity. Criminology, 22(1), 39-59.

Fareri, D. S., Chang, L. J., \& Delgado, M. R. (2015). Computational Substrates of Social Value in Interpersonal Collaboration. The Journal of Neuroscience, 35(21), 8170-8180. 
Fehr, E., \& Gächter, S. (2000). Cooperation and punishment in public goods experiments. American Economic Review, 90(4), 980-994.

Fehr, E., \& Schmidt, K. M. (1999). A theory of fairness, competition, and cooperation. The Quarterly Journal of Economics, 114, 817-868.

Fiddick, L. (2008). Which norms are strong reciprocators supposed to enforce? Not all norms are psychologically the same. International Review of Economics, 55(1-2), 77-89.

Fiddick, L., Cosmides, L., \& Tooby, J. (2000). No interpretation without representation: The role of domain-specific representations and inferences in the Wason selection task. Cognition, $77,1-79$.

Fiske, S. T. (2011). Envy up, scorn down: How status divides us. Russell Sage Foundation.

Fiske, S. T., Cuddy, A. J., \& Glick, P. (2007). Universal dimensions of social cognition: Warmth and competence. Trends in Cognitive Sciences, 11(2), 77-83.

Foster, G. M. (1965). Peasant Society and the Image of Limited Good. American Anthropologist, 67, 293-315.

Frank, R. H. (2005). Positional externalities cause large and preventable welfare losses. American Economic Review, 95(2), 137-141.

Fridman, G. H. L. (1985). The necessity for writing in contracts within the Statute of Frauds. The University of Toronto Law Journal, 35(1), 43-66.

Gee, L. K., Migueis, M., \& Parsa, S. (2017). Redistributive choices and increasing income inequality: Experimental evidence for income as a signal of deservingness. Experimental Economics, 20(4), 894-923.

Gershman, B. (2014). The two sides of envy. Journal of Economic Growth, 19(4), 407-438.

Giffin, C., \& Lombrozo, T. (2016). Wrong or merely prohibited: Special treatment of strict liability in intuitive moral judgment. Law and Human Behavior, 40(6), 707.

Gigerenzer, G., \& Hug, K. (1992). Domain-Specific Reasoning-Social Contracts, Cheating, and Perspective Change. Cognition, 43, 127-171.

Gilens, M. (2009). Why Americans hate welfare: Race, media, and the politics of antipoverty policy. University of Chicago Press.

Goody, J. (1986). The logic of writing and the organization of society. Cambridge University Press.

Graham, J., Haidt, J., \& Nosek, B. A. (2009). Liberals and Conservatives Rely on Different Sets of Moral Foundations. Journal of Personality and Social Psychology, 96, 1029-1046.

Gray, K., Waytz, A., \& Young, L. (2012). The moral dyad: A fundamental template unifying moral judgment. Psychological Inquiry, 23(2), 206-215.

Greene, J. D., Nystrom, L. E., Engell, A. D., Darley, J. M., \& Cohen, J. D. (2004). The neural bases of cognitive conflict and control in moral judgment. Neuron, 44(2), 389-400.

Gurven, M. (2004). To give and to give not: The behavioral ecology of human food transfers. Behavioral and Brain Sciences, 27(4), 543-559.

Guzmán, R. A., Barbato. M. T., Sznycer, D., \& Cosmides, L. (under review). A moral tradeoff system produces intuitive judgments that are rational and strike a balance between conflicting moral duties.

Halperin, E., Russell, A. G., Dweck, C. S., \& Gross, J. J. (2011). Anger, hatred, and the quest for peace: Anger can be constructive in the absence of hatred. Journal of Conflict Resolution, 55(2), 274-291. 
Hamilton, M. J., Burger, O., DeLong, J. P., Walker, R. S., Moses, M. E., \& Brown, J. H. (2009). Population stability, cooperation, and the invasibility of the human species. Proceedings of the National Academy of Sciences, 106(30), 12255-12260.

Hamilton, W. D. (1964). The genetical evolution of social behaviour. Journal of Theoretical Biology, 7(1), 17-52.

Hamlin, J. K., Wynn, K., Bloom, P., \& Mahajan, N. (2011). How infants and toddlers react to antisocial others. Proceedings of the National Academy of Sciences, 108(50), 1993119936.

Hammerstein, P., \& Parker, G. A. (1982). The asymmetric war of attrition. Journal of Theoretical Biology, 96(4), 647-682.

Hansen, K. J. (under review). Greed, Envy, and Admiration: The Distinct Nature of Public Opinion about Redistribution from the Rich.

Hare, T. A., Camerer, C. F., Knoepfle, D. T., O’Doherty, J. P., \& Rangel, A. (2010). Value computations in ventral medial prefrontal cortex during charitable decision making incorporate input from regions involved in social cognition. Journal of Neuroscience, 30(2), 583-590.

Hasenfeld, Y., \& Rafferty, J. A. (1989). The determinants of public attitudes toward the welfare state. Social Forces, 67(4), 1027-1048.

Henrich, J. (2020). The WEIRDest people in the world: How the West became psychologically peculiar and particularly prosperous. Penguin UK.

Herrmann, B., Thöni, C., \& Gächter, S. (2008). Antisocial punishment across societies. Science, 319(5868), 1362-1367.

Hill, K., \& Hurtado, A. M. (1996). Ache life history: The ecology and demography of a foraging people. de Gruyter.

Hook, J. G., \& Cook, T. D. (1979). Equity theory and the cognitive ability of children. Psychological Bulletin, 86(3), 429-445.

Hundley, G., \& Kim, J. (1997). National culture and the factors affecting perceptions of pay fairness in Korea and the United States. The International Journal of Organizational Analysis, 5, 325-341.

Huntingford, F. A., \& Turner, A. (1987). Animal conflict. Chapman \& Hall.

Inglehart, R. F. (2008). Changing values among western publics from 1970 to 2006. West European Politics, 31(1-2), 130-146.

Inglehart, R. F., Ponarin, E., \& Inglehart, R. C. (2017). Cultural change, slow and fast: The distinctive trajectory of norms governing gender equality and sexual orientation. Social Forces, 95(4), 1313-1340.

Jakobsen, T. G., \& Listhaug, O. (2012). Issue ownership, unemployment and support for government intervention. Work, Employment and Society, 26(3), 396-411.

Johnson, S. G., Zhang, J., \& Keil, F. C. (2021). Win-win denial: The psychological underpinnings of zero-sum thinking. Journal of Experimental Psychology: General.

Johnson, W. (2014). The T'ang Code, Volume II: Specific Articles (Vol. 103). Princeton University Press.

Jones, O. D. (2001). Proprioception, non-law, and biolegal history. Florida Law Review, 53(5), $831-874$.

Jones, O. D., \& Goldsmith, T. H. (2005). Law and behavioral biology. Columbia Law Review, $105(2), 405-502$. 
Kääriäinen, J. (2018). Seven criminal cases-Comparing Finnish Punishment policies and Finns' punishment preferences. Helsinki, Finland: University of Helsinki Institute of Criminology and Legal Policy, Research Report 27/2018.

Kahan, D. M. (2015). Laws of cognition and the cognition of law. Cognition, 135, 56-60.

Kameda, T., Takezawa, M., \& Hastie, R. (2003). The logic of social sharing: An evolutionary game analysis of adaptive norm development. Personality and Social Psychology Review, 7, 2-19.

Kameda, T., Takezawa, M., Tindale, R. S., \& Smith, C. M. (2002). Social sharing and risk reduction-Exploring a computational algorithm for the psychology of windfall gains. Evolution and Human Behavior, 23, 11-33.

Kaplan, H., \& Hill, K. (1985). Food sharing among ache foragers: Tests of explanatory hypotheses. Current Anthropology, 26, 223-239.

Kaplan, H., Hill, K., Lancaster, J., \& Hurtado, A. M. (2000). A theory of human life history evolution: Diet, intelligence, and longevity. Evolutionary Anthropology: Issues, News, and Reviews: Issues, News, and Reviews, 9(4), 156-185.

Kaplan, H. S., Schniter, E., Smith, V. L., \& Wilson, B. J. (2012). Risk and the evolution of human exchange. Proceedings of the Royal Society of London B: Biological Sciences, rspb20112614.

Kaplan, H. S., Schniter, E., Smith, V. L., \& Wilson, B. J. (2018). Experimental tests of the tolerated theft and risk-reduction theories of resource exchange. Nature Human Behaviour, 2(6), 383-388.

Kebede, B., \& Zizzo, D. J. (2011). Envy and agricultural innovation: An experimental case study from ethiopia. Centre for Behavioural and Experimental Social Science (CBESS) Discussion Paper, 11-12.

Keeley, L. H. (1997). War before civilization. Oxford University Press.

Keltner, D., Young, R. C., \& Buswell, B. N. (1997). Appeasement in human emotion, social practice, and personality. Aggressive Behavior, 23(5), 359-374.

Kiatpongsan, S., \& Norton, M. I. (2014). How much (more) should CEOs make? A universal desire for more equal pay. Perspectives on Psychological Science, 9, 587-593.

Klein, J. T., Deaner, R. O., \& Platt, M. L. (2008). Neural correlates of social target value in macaque parietal cortex. Current Biology, 18(6), 419-424.

Kneer, M., \& Bourgeois-Gironde, S. (2017). Mens rea ascription, expertise and outcome effects: Professional judges surveyed. Cognition, 169, 139-146.

Krasnow, M. M., Delton, A. W., Cosmides, L., \& Tooby, J. (2016). Looking under the hood of third-party punishment reveals design for personal benefit. Psychological Science, 27(3), 405-418.

Kuran, T. (2005). The absence of the corporation in Islamic law: Origins and persistence. The American Journal of Comparative Law, 53(4), 785-834.

Landes, D. S. (2015). Wealth and poverty of nations. Hachette UK.

Leary, M. R., \& Baumeister, R. F. (2000). The nature and function of self-esteem: Sociometer theory. Advances in Experimental Social Psychology, 32, 1-62.

Lee, R. B. (1979). The! Kung San: Men, women and work in a foraging society. Cambridge University Press.

Levy, D. J., \& Glimcher, P. W. (2012). The root of all value: A neural common currency for choice. Current Opinion in Neurobiology, 22(6), 1027-1038. 
Liberman, V., Samuels, S. M., \& Ross, L. (2004). The name of the game: Predictive power of reputations versus situational labels in determining prisoner's dilemma game moves. Personality and Social Psychology Bulletin, 30(9), 1175-1185.

Lieberman, D., \& Linke, L. (2007). The effect of social category on third party punishment. Evolutionary Psychology, 5(2), 147470490700500200.

Lieberman, D., \& Patrick, C. (2018). Objection: Disgust, morality, and the law. Oxford University Press.

Lieberman, D., Tooby, J., \& Cosmides, L. (2007). The architecture of human kin detection. Nature, 445(7129), 727.

Liénard, P., Chevallier, C., Mascaro, O., Kiura, P., \& Baumard, N. (2013). Early understanding of merit in Turkana children. Journal of Cognition and Culture, 13(1-2), 57-66.

Lin, C.-A., \& Bates, T. C. (2021). Who supports redistribution? Replicating and refining effects of compassion, malicious envy, and self-interest. Evolution and Human Behavior, 42(2), $140-147$.

Locke, J. (1988). Two Treatises of Government. Cambridge University Press.

Lukaszewski, A. W., Simmons, ZL, Anderson, C, \& Roney JR. (2015). The role of physical formidability in human social status allocation. Journal of Personality and Social Psychology, 110, 385-406.

Maljkovic, V. (1987). Reasoning in evolutionarily important domains and schizophrenia: Dissociation between content-dependent and content independent reasoning. Unpublished Honors Thesis, Department of Psychology, Harvard University.

Masclet, D., Noussair, C., Tucker, S., \& Villeval, M. C. (2003). Monetary and nonmonetary punishment in the voluntary contributions mechanism. American Economic Review, 93, 366-380.

McAuliffe, K., Jordan, J. J., \& Warneken, F. (2015). Costly third-party punishment in young children. Cognition, 134, 1-10.

McClendon, G. H. (2012). The politics of envy and esteem in two democracies.

McNamara, R. A., Willard, A. K., Norenzayan, A., \& Henrich, J. (2019). Weighing outcome vs. intent across societies: How cultural models of mind shape moral reasoning. Cognition, $182,95-108$.

Mercier, H., \& Sperber, D. (2011). Why do humans reason? Arguments for an argumentative theory. Behavioral and Brain Sciences, 34(2), 57-74.

Mikhail, J. (2007). Universal moral grammar: Theory, evidence and the future. Trends in Cognitive Sciences, 11(4), 143-152.

Mikhail, J. (2009). Is the Prohibition of Homicide Universal-Evidence from Comparative Criminal Law. Brooklyn Law Review, 75, 497-515.

Moon, M. (1984). Economic transfers in the United States. University of Chicago Press.

Nancekivell, S. E., Friedman, O., \& Gelman, S. A. (2019). Ownership matters: People possess a naïve theory of ownership. Trends in Cognitive Sciences, 23(2), 102-113.

Nelken, D. (2011). Comparative criminal justice and globalization. Ashgate Publishing, Ltd.

Nettle, D., \& Saxe, R. (2020). Preferences for redistribution are sensitive to perceived luck, social homogeneity, war and scarcity. Cognition, 198, 104234.

Neumeyer, M. (1968). Challenge of crime in a free society: Presidents commission on law enforcement and administration of justice.

Newman, G. R., \& Wolfgang, M. E. (2017). Comparative deviance: Perception and law in six cultures. Routledge. 
North, D. C. (1990). Institutions, institutional change and economic performance. Cambridge University Press.

Norton, M. I., \& Ariely, D. (2011). Building a better America-One wealth quintile at a time. Perspectives on Psychological Science, 6, 9-12.

Nowak, M. A., \& Sigmund, K. (1998). Evolution of indirect reciprocity by image scoring. Nature, 393(6685), 573-577.

O’Neill, P., \& Petrinovich, L. (1998). A preliminary cross-cultural study of moral intuitions. Evolution and Human Behavior, 19(6), 349-367.

Ostrom, E. (1990). Governing the commons: The evolution of institutions for collective action. Cambridge University Press.

Patrick, C. (This issue). Evolution is the source, and the undoing, of natural law. Evolution and Human Behavior.

Patrick, C. J. (2016). The Long-Term Promise of Evolutionary Psychology for the Law. Arizona State Law Journal, 48, 995-1012.

Patrick, C. J., \& Lieberman, D. (2017). Not from a Wicked Heart: Testing the Assumptions of the Provocation Doctrine. Nevada Law Journal, 18, 33-59.

Pedersen, E. J., Kurzban, R., \& McCullough, M. E. (2013). Do humans really punish altruistically? A closer look. Proceedings of the Royal Society of London B: Biological Sciences, 280(1758), 20122723.

Petersen, M. B. (2012). Social welfare as small-scale help: Evolutionary psychology and the deservingness heuristic. American Journal of Political Science, 56(1), 1-16.

Petersen, M. B. (2015). Evolutionary political psychology: On the origin and structure of heuristics and biases in politics. Political Psychology, 36, 45-78.

Petersen, M. B., Sell, A., Tooby, J., \& Cosmides, L. (2012). To punish or repair? Evolutionary psychology and lay intuitions about modern criminal justice. Evolution and Human Behavior, 33(6), 682-695.

Petersen, M. B., Slothuus, R., Stubager, R., \& Togeby, L. (2011). Deservingness versus values in public opinion on welfare: The automaticity of the deservingness heuristic. European Journal of Political Research, 50(1), 24-52.

Petersen, M. B., Sznycer, D., Cosmides, L., \& Tooby, J. (2012). Who deserves help? Evolutionary psychology, social emotions, and public opinion about welfare. Political Psychology, 33, 395-418.

Petersen, M. B., Sznycer, D., Sell, A., Cosmides, L., \& Tooby, J. (2013). The Ancestral logic of politics: Upper-body strength regulates men's assertion of self interest over economic redistribution. Psychological Science, 24(7), 1098-1103.

Pinker, S. (2003). The language instinct: How the mind creates language. Penguin UK.

Pinker, S. (2010). The cognitive niche: Coevolution of intelligence, sociality, and language. Proceedings of the National Academy of Sciences, 107, 8993-8999.

Pinker, S. (2011). The better angels of our nature: Why violence has declined. Penguin.

Plaut, W. G., \& Bamberger, B. J. (1981). The Torah. A modern commentary. Union of American Hebrew Congregations.

Posner, R. A. (2010). How judges think. Harvard University Press.

Price, M. E., Sheehy-Skeffington, J., Sidnaius, J., \& Pound, N. (2017). Is sociopolitical egalitarianism related to bodily and facial formidability in men? Evolution and Human Behavior, 38(5), 626-634. 
Raihani, N. J., Grutter, A. S., \& Bshary, R. (2010). Punishers benefit from third-party punishment in fish. Science, 327(5962), 171-171.

Raihani, N. J., \& McAuliffe, K. (2012). Human punishment is motivated by inequity aversion, not a desire for reciprocity. Biology Letters, 8(5), 802-804.

Rawls, J. (1971). A theory of justice. Harvard University Press.

Richerson, P., \& Henrich, J. (2009). Tribal social instincts and the cultural evolution of institutions to solve collective action problems. Context and the Evolution of Mechanisms for Solving Collective Action Problems Paper.

Robbins, E., Shepard, J., \& Rochat, P. (2017). Variations in judgments of intentional action and moral evaluation across eight cultures. Cognition, 164, 22-30.

Robinson, P. H., Goodwin, G. P., \& Reisig, M. D. (2010). The disutility of injustice. New York University Law Review, 85, 1940-2033.

Robinson, P H, \& Kurzban, R. (2007). Concordance and conflict in intuitions of justice. Minnesota Law Review, 91, 1829-1907.

Robinson, P. H., Kurzban, R., \& Jones, O. D. (2007). The origins of shared intuitions of justice. Vanderbilt Law Review, 60(6), 1633-1688.

Rochat, P., Robbins, E., Passos-Ferreira, C., Oliva, A. D., Dias, M. D., \& Guo, L. (2014). Ownership reasoning in children across cultures. Cognition, 132(3), 471-484.

Rossano, F., Rakoczy, H., \& Tomasello, M. (2011). Young children's understanding of violations of property rights. Cognition, 121(2), 219-227.

Roth, M. T., Hoffner, H. A., \& Michalowski, P. (1997). Law collections from Mesopotamia and Asia minor. Scholars Press.

Różycka-Tran, J., Boski, P., \& Wojciszke, B. (2015). Belief in a zero-sum game as a social axiom: A 37-nation study. Journal of Cross-Cultural Psychology, 46(4), 525-548.

Saguy, A. C., \& Stuart, F. (2008). Culture and law: Beyond a paradigm of cause and effect. Annals of the American Academy of Political and Social Science, 619(1), 149-164.

Schoeck, H. (1987). Envy: A theory of social behavior. Liberty Fund.

Sears, D. O., Lau, R. R., Tyler, T. R., \& Allen, H. M. (1980). Self-interest vs. Symbolic politics in policy attitudes and presidential voting. American Political Science Review, 74(03), $670-684$.

Sell, A. (2012). Revenge can be more fully understood by making distinctions between anger and hatred. Commentary on McCullough, Kurzan \& Tabak's "Cognitive Systems for Revenge and Forgiveness." Behavioral and Brain Sciences. https://doi.org/10.1017/S0140525X11002160

Sell, A., Bryant, G. A., Cosmides, L., Tooby, J., Sznycer, D., von Rueden, C., Krauss, A., \& Gurven, M. (2010). Adaptations in humans for assessing physical strength from the voice. Proceedings of the Royal Society B: Biological Sciences, 277, 3509-3518.

Sell, A., Cosmides, L., Tooby, J., Sznycer, D., von Rueden, C., \& Gurven, M. (2009). Human adaptations for the visual assessment of strength and fighting ability from the body and face. Proceedings of the Royal Society of London B: Biological Sciences, 276(1656), 575-584.

Sell, A. N., \& Lopez, A. C. (2020). Emotional underpinnings of war: An evolutionary analysis of anger and hatred. In The Handbook of Collective Violence (pp. 31-46). Routledge.

Sell, A., Scrivner, C., Landers, M., \& Lopez, A. (2021). The Neutralization Theory of Hatred. 
Sell, A \& Sznycer, D. (in press). The recalibrational theory: Anger as a bargaining emotion. In The Oxford Handbook of Evolution and the Emotions (L. Al-Shawaf \& T. K. Shackelford, Eds.). Oxford University Press.

Sell, A., Sznycer, D., Al-Shawaf, L., Lim, J., Krauss, A., Feldman, A., Rascanu, R., Sugiyama, L., Cosmides, L., \& Tooby, J. (2017). The grammar of anger: Mapping the computational architecture of a recalibrational emotion. Cognition, 168, 110-128.

Sell, A., Tooby, J., \& Cosmides, L. (2009). Formidability and the logic of human anger. Proceedings of the National Academy of Sciences of the United States of America, 106, 15073-15078.

Shaw, A. (2013). Beyond "to share or not to share" The impartiality account of fairness. Current Directions in Psychological Science, 22(5), 413-417.

Shaw, A., \& Olson, K. (2014). Fairness as partiality aversion: The development of procedural justice. Journal of Experimental Child Psychology, 119, 40-53.

Smetana, J. G. (1981). Preschool children's conceptions of moral and social rules. Child Development, 1333-1336.

Smith, R. H., \& Kim, S. H. (2007). Comprehending envy. Psychological Bulletin, 133(1), $46-64$.

Sowell, T. (2021). Conquests and cultures: An international history. Basic Books.

Sperber, D. (1996). Explaining culture: A naturalistic approach. Cambridge, MA: Cambridge.

Sperber, D. (1997). Intuitive and reflective beliefs. Mind \& Language, 12, 67-83.

Stevenson, M. C., Sorenson, K. M., Smith, A. C., Sekely, A., \& Dzwairo, R. A. (2009). Effects of defendant and victim race on perceptions of juvenile sex offenders. Behavioral Sciences \& the Law, 27(6), 957-979.

Strum, S. C. (1981). Processes and Products of Change: Baboon Predatory Behavior at Gilgil, Kenya. In Omnivorous primates. Gathering and hunting in human evolution (pp. 255302). Columbia University Press.

Stylianou, S. (2003). Measuring crime seriousness perceptions: What have we learned and what else do we want to know. Journal of Criminal Justice, 31(1), 37-56.

Sugiyama, L. S. (2004). Illness, injury, and disability among Shiwiar forager-horticulturists: Implications of health-risk buffering for the evolution of human life history. American Journal of Physical Anthropology, 123, 371-389.

Sunstein, C. R. (1999). The law of group polarization. University of Chicago Law School, John M. Olin Law \& Economics Working Paper, 91.

Sznycer, D. (2019). Forms and functions of the self-conscious emotions. Trends in Cognitive Sciences, 23(2), 143-157.

Sznycer, D. (under review). Value computation in humans: A functional perspective. https://psyarxiv.com/mkde7

Sznycer, D., Al-Shawaf, L., Bereby-Meyer, Y., Curry, O. S., De Smet, D., Ermer, E., Kim, S., Kim, S., Li, N. P., Lopez Seal, M. F., McClung, J., O, J., Ohtsubo, Y., Quillien, T., Schaub, M., Sell, A., van Leeuwen, F., Cosmides, L., \& Tooby, J. (2017). Cross-cultural regularities in the cognitive architecture of pride. Proceedings of the National Academy of Sciences, 114(8), 1874-1879.

Sznycer, D., Barlev, M., Lopez Seal, F., Tooby, J., \& Cosmides, L. (forthcoming). The psychology of zero-sum games.

Sznycer, D., Ermer, E., \& Tooby, J. (2018). Why do people think that others should earn this or that? Behavioral and Brain Sciences, 41. 
Sznycer, D., Lopez Seal, M. F., Sell, A., Lim, J., Porat, R., Shalvi, S., Halperin, E., Cosmides, L., \& Tooby, J. (2017). Support for redistribution is shaped by compassion, envy, and selfinterest, but not a taste for fairness. Proceedings of the National Academy of Sciences, $114(31), 8420-8425$.

Sznycer, D., \& Patrick, C. (2020). The origins of criminal law. Nature Human Behaviour, 4(5), 506-516.

Sznycer, D., Sell, A., \& Dumont, A. (in press). How anger works. Evolution and Human Behavior.

Sznycer, D., Sell, A., \& Lieberman, D. (2021). Forms and functions of the social emotions. Current Directions in Psychological Science, 30(4), 292-299.

Sznycer, D., Tooby, J., Cosmides, L., Porat, R., Shalvi, S., \& Halperin, E. (2016). Shame closely tracks the threat of devaluation by others, even across cultures. Proceedings of the National Academy of Sciences, 113(10), 2625-2630.

Sznycer, D., Xygalatas, D., Agey, E., Alami, S., An, X.-F., Ananyeva, K. I., Atkinson, Q. D., Broitman, B. R., Conte, T. J., Flores, C., Fukushima, S., Hitokoto, H., Kharitonov, A. N., Onyishi, C. N., Onyishi, I. E., Romero, P. P., Schrock, J. M., Snodgrass J. J., Sugiyama, L. S., Takemura, K., Townsend, C., Zhuang, J.-Y., Aktipis, C. A., Cronk, L., Cosmides, L., \& Tooby, J. (2018). Cross-cultural invariances in the architecture of shame. Proceedings of the National Academy of Sciences, 115(39), 9702-9707.

Sznycer, D., Xygalatas, D., Alami, S., An, X.-F., Ananyeva, K. I., Fukushima, S., Hitokoto, H., Kharitonov, A. N., Koster, J. M., Onyishi, C. N., Onyishi, I. E., Romero, P. P., Takemura, K., Zhuang, J.-Y., Cosmides, L., \& Tooby, J. (2018). Invariances in the architecture of pride across small-scale societies. Proceedings of the National Academy of Sciences, $115(33), 8322-8327$.

Taylor, S. E., Fiske, S. T., Etcoff, N. L., \& Ruderman, A. J. (1978). Categorical and Contextual Bases of Person Memory and Stereotyping. Journal of Personality and Social Psychology, 36, 778-793.

Thibaut, J., Walker, L., LaTour, S., \& Houlden, P. (1974). Procedural justice as fairness. Stanford Law Review, 26, 1271-1289.

Tocqueville, A. (2003). Democracy in America: And Two essays on America. Penguin UK.

Tomasello, M. (2011). Human culture in evolutionary perspective. Advances in Culture and Psychology, 1, 5-51.

Tomasello, M., Melis, A. P., Tennie, C., Wyman, E., \& Herrmann, E. (2012). Two key steps in the evolution of human cooperation: The interdependence hypothesis. Current Anthropology, 53(6), 673-692.

Tooby, J., \& Cosmides, L. (1990). On the universality of human nature and the uniqueness of the individual: The role of genetics and adaptation. Journal of Personality, 58(1), 17-67.

Tooby, J., \& Cosmides, L. (1992). The psychological foundations of culture. In J. Barkow, L. Cosmides, \& J. Tooby (Eds.), The adapted mind: Evolutionary psychology and the generation of culture (pp. 19-136). Oxford University Press.

Tooby, J., \& Cosmides, L. (2010). Groups in mind: The coalitional roots of war and morality. In Human morality and sociality: Evolutionary and comparative perspectives (H. HøghOlesen, Ed.) (pp. 191-234). Palgrave MacMillan.

Tooby, J., \& Cosmides, L. (1996). Friendship and the banker's paradox: Other pathways to the evolution of adaptations for altruism. Proceedings-British Academy, 88, 119-144. 
Tooby, J., Cosmides, L., Sell, A., Lieberman, D., \& Sznycer, D. (2008). Internal regulatory variables and the design of human motivation: A computational and evolutionary approach. In Handbook of approach and avoidance motivation (Andrew J. Elliot (Ed.), pp. 251-271). Lawrence Erlbaum Associates.

Trivers, R. L. (1971). The evolution of reciprocal altruism. The Quarterly Review of Biology, 46(1), 35-57.

Tullock, G. (1983). Economics of income redistribution. Kluwer-Nijhof.

Tyran, J.-R., \& Sausgruber, R. (2006). A little fairness may induce a lot of redistribution in democracy. European Economic Review, 50(2), 469-485.

United States Code, Supplement 5, Title 18-Crimes and Criminal Procedure (2006th ed.). (2011). https://www.govinfo.gov/app/details/USCODE-2011-title18

United States Code, Title 26, Internal Revenue Code (Vols. 18 \& 19). (2012).

Van Der Schalk, J., Bruder, M., \& Manstead, A. (2012). Regulating emotion in the context of interpersonal decisions: The role of anticipated pride and regret. Frontiers in Psychology, $3,1-9$.

Von Mises, L. (1951). Socialism: An Economic and Sociological Analysis. Macmillan Company.

von Rueden, C., Gurven, M., \& Kaplan, H. (2008). The multiple dimensions of male social status in an Amazonian society. Evolution and Human Behavior, 29, 402-415.

Weisfeld, G. E., \& Dillon, L. M. (2012). Applying the dominance hierarchy model to pride and shame, and related behaviors. Journal of Evolutionary Psychology, 10(1), 15-41.

Wiessner, P. (1982). Beyond Willow Smoke and Dogs' Tails: A Comment on Binford's Analysis of Hunter-Gatherer Settlement Systems. American Antiquity, 47(1), 171-178.

Wiessner, P. (2020). The role of third parties in norm enforcement in customary courts among the Enga of Papua New Guinea. Proceedings of the National Academy of Sciences, $117(51), 32320-32328$.

Williams, K. E., Votruba, A. M., Neuberg, S. L., \& Saks, M. J. (2019). Capital and punishment: Resource scarcity increases endorsement of the death penalty. Evolution and Human Behavior, 40(1), 65-73.

Williamson, J. B. (1974). Beliefs about the motivation of the poor and attitudes toward poverty policy. Social Problems, 21(5), 634-648.

Wilson, M., \& Daly, M. (1997). Life expectancy, economic inequality, homicide, and reproductive timing in Chicago neighbourhoods. Bmj, 314(7089), 1271.

Winterhalder, B. (1986). Diet choice, risk, and food sharing in a stochastic environment. Journal of Anthropological Archaeology, 5, 369-392.

Wobker, I. (2015). The price of envy-An experimental investigation of spiteful behavior. Managerial and Decision Economics, 36(5), 326-335.

Wrangham, R. W. (2018). Two types of aggression in human evolution. Proceedings of the National Academy of Sciences, 115(2), 245-253.

Wu, J., Balliet, D., \& Van Lange, P. A. (2016). Gossip versus punishment: The efficiency of reputation to promote and maintain cooperation. Scientific Reports, 6(1), 1-8.

Xiao, E., \& Houser, D. (2005). Emotion expression in human punishment behavior. Proceedings of the National Academy of Sciences, 102(20), 7398-7401.

Yamagishi, T., Hashimoto, H., \& Schug, J. (2008). Preferences versus strategies as explanations for culture-specific behavior. Psychological Science, 19(6), 579-584.

Young, L., \& Saxe, R. (2011). When ignorance is no excuse: Different roles for intent across moral domains. Cognition, 120(2), 202-214. 
Running Head: JUSTICE-MAKING INSTITUTIONS

Zizzo, D. J., \& Oswald, A. J. (2001). Are people willing to pay to reduce others' incomes? Annales d'Economie et de Statistique, 39-65. 